\title{
Daya Saing Produk Kelapa Indonesia dan Eksportir Kelapa Utama Lainnya Di Pasar Global
}

\section{Coconut Product's Competitiveness of Indonesia and Other Coconut Exporter Countries In Global Market}

\section{Hanief Al Naufal ${ }^{1}$ dan Suprehatin ${ }^{1 *}$}

${ }^{1,}$ Departemen Agribisnis, Fakultas Ekonomi dan Manajemen, Institut Pertanian Bogor

*E-mail: suprehatin@apps.ipb.ac.id

\begin{abstract}
The global value chains increase competitiveness of the trade of agricultural and food products including coconut and its derivatives products such as coconut oil and copra. This study aims to analyze the position and correlation of Indonesia's coconut competitiveness among other top exporter countries in the global market. The Trademap's panel data from 2012 to 2017 are used and analyzed by Revealed Symmetric Comparative Advantage (RSCA), Trade Specialization Index (ISP), and rank Spearman correlation. The results show that all Indonesian coconut products have competitiveness in the global market and already reach a mature phase. The highest competitiveness of the Indonesia coconut products is coconut in the inner shell. The results also show that Indonesia has a strong competitive correlation with The Philippines, Thailand, and Papua New Guinea for three different coconut products.
\end{abstract}

Keywords: copra, global value chain ISP, RSCA

Disubmit: 26 Maret 2021; Diterima: 4 April 2021; Disetujui: 14 April 2021

\section{PENDAHULUAN}

Kelapa telah menjadi bagian dari kehidupan masyarakat pesisir di berbagai wilayah dunia mulai dari Afrika Barat, Karibia, pesisir Atlantik, pesisir Pasifik hingga Amerika Selatan dan Amerika Tengah sejak lebih dari lima ratus tahun yang lalu (Bourdeix and Prades, 2018). Hal ini dikarenakan kelapa memiliki banyak manfaat pada seluruh bagian tanamannya mulai dari buah, daun, batang hingga akar. Hingga saat ini, kelapa banyak dimanfaatkan baik dalam bentuk primer maupun manufaktur. Produk primer kelapa adalah produk yang masih menunjukkan ciri-ciri buah kelapa sedangkan produk manufaktur kelapa merupakan produk olahan kelapa yang tidak lagi menunjukkan ciri-ciri buah kelapa (Pusdatin, 2017). Contoh produk primer kelapa adalah kelapa parut atau kering (dessicated coconuts, kode Harmonized System (HS) 080111), kelapa di dalam kulit (fresh coconuts in the inner shell "endocarp", kode HS 080112), kelapa segar serta olahannya (fresh coconuts, whether or not shelled or peeled, excluding in the inner shell "endocarp", kode HS 080119) dan kopra (copra, kode HS 120300). Sementara itu, contoh produk manufaktur kelapa adalah minyak kelapa mentah (crude coconut oil, kode HS 15311), minyak kelapa serta turunannya (other coconut oil and its fractions, kode HS 15319), bungkil kelapa (coconut cake, kode HS 230650), arang kelapa (coconut chorcoal, kode HS 440290) dan serat kelapa (coconut fibers, kode HS 530500) (Pusdatin, 2017). 
Permintaan global terhadap produk kelapa dan turunan kelapa terus mengalami perubahan dan peningkatan seiring perkembangan rantai nilai global (global value chains, GVC). Pertama, terdapat dua produk turunan kelapa yang baru tercatat di perdagangan global yaitu serat kelapa pada tahun 2005 dan arang kelapa pada tahun 2006. Kedua, total impor kelapa di pasar global terus mengalami peningkatan. Pada periode 2012-2017, kelapa parut atau kering merupakan produk primer kelapa yang paling banyak diimpor di pasar global (Trademap, 2019). Nilai rata-rata pertumbuhan impor produk primer kelapa tersebut paling tinggi yaitu sebesar $1.32 \%$, lebih besar dari produk primer kelapa lainnya seperti kelapa segar dan olahannya (1.21\%), kelapa di dalam kulit (1.14\%) dan kopra (1.07\%) (Trademap, 2019). Di lain sisi, permintaan impor terbesar untuk produk manufaktur kelapa di pasar global adalah minyak kelapa mentah. Meskipun demikian, rata-rata pertumbuhan nilai impor produk manufaktur kelapa paling tinggi di pasar global adalah minyak kelapa dan turunannya yaitu sebesar $1.45 \%$ diikuti produk arang kelapa $(1.41 \%)$, minyak kelapa mentah $(1.36 \%)$, serat kelapa (1.28\%) dan bungkil kelapa (0.91\%) (Trademap, 2019).

Perkembangan GVC dan permintaan global terhadap produk kelapa memberikan peluang ekspor untuk Indonesia sebagai salah satu produsen utama kelapa dunia. Luas area perkebunan kelapa Indonesia merupakan terluas di dunia yaitu sekitar 3.57 juta hektar atau 31\% dari total area kebun kelapa di dunia (Ditjenbun, 2016). Meskipun demikian, hal ini bukan berarti Indonesia memiliki keunggulan absolut (absolute competitive) terhadap produk kelapa dan turunan kelapa di pasar global. Negara lain baik produsen maupun bukan produsen kelapa utama dunia terus mengembangkan keunggulan komparatif dan kompetitif (comparative and competitive advantages) kelapa mereka agar bisa berdaya saing di pasar global. Lebih dari itu, perkembangan GVC pada produk pangan dan pertanian dapat menjadi tantangan tersendiri bagi Indonesia. Kemampuan memanfaatkan teknologi dan informasi yang terus berkembang, sumber daya manusia yang unggul dan kebijakan pemerintah yang kondusif memungkinkan negara-negara yang bukan produsen utama kelapa dapat menjadi eksportir utama kelapa di pasar global diantaranya untuk produk turunan kelapa. Sebagai contoh, Belanda, Belgia dan Jerman sebagai negara bukan produsen kelapa namun merupakan negara eksportir utama produk kelapa parut atau kering di pasar Eropa. Pangsa ekspor kelapa parut atau kering Belanda, Belgia dan Jerman di pasar Eropa masing-masing sebesar 38.0\%, 36.0\% dan 13.0\%, diikuti Inggris (3.0\%) dan Polandia (2.0\%). Negara-negara tersebut melakukan impor dari negara produsen utama kelapa dunia dan kemudian mengekspor kelapa parut atau kering ke pasar Eropa seperti Rusia, Switzerland dan Maroko (CBI, 2015). Contoh tersebut menunjukkan bahwa perkembangan GVC membuat Indonesia tidak hanya bersaing dengan negara produsen utama kelapa namun juga bersaing dengan negara-negara lainnya di pasar global.

Berdasarkan hal tersebut, pemahaman mengenai posisi daya saing dari produk kelapa dan turunan kelapa Indonesia di pasar global penting untuk diketahui agar langkah-langkah pengembangan agribisnis kelapa Indonesia pada masing-masing produk tersebut dapat berdaya saing secara berkelanjutan. Daya saing ekspor, termasuk daya saing suatu produk, sudah dikenal luas sebagai media untuk mencapai keunggulan dan daya saing di pasar global (Caporale, Spagnolo \& Spagnolo, 2018; Dhiman, Kumar \& Rana, 2020; Paul \& Dhiman, 2021). Secara definisi, daya saing mengacu pada kemampuan suatu negara untuk memasarkan produk yang dihasilkan relative dibandingkan kemampuan negara lain (Porter, 2011). Dalam arti lain, daya saing merupakan kemampuan peodusen untuk memproduksi dan menjual barang atau jasa pada tempat yang membutuhkan dan harga yang bersaing dibandingkan dengan produsen lainnya (Sharples \& Milham, 1990).

Pada dasarnya, penelitian mengenai kelapa Indonesia sudah banyak dilakukan mulai dari hulu hingga hilir. Pada industri pengolahan Dharmawan et al. (2020) meneliti tekno-ekonomis tempurung kelapa. Pada aspek ekonomi, penelitian mengenai daya saing dan posisi kelapa Indonesia di pasar global sudah pernah dilakukan namun untuk produk manufaktur kelapa (Subangka, 2017; Subekti, Hadi and Tety, 2018; Aulia et al., 2020) dan kelapa secara keseluruhan (Widyantari, 2013). Penelitian-penelitian tersebut sejalan dengan penelitian daya saing untuk produk unggulan ekspor Indonesia lainnya seperti kelapa sawit (Rifin, 2019), 
kakao (Tresliyana, Fariyanti \& Rifin, 2015), pala (Asrol \& Heriyanto, 2017), teh (Satryana \& Karmini, 2016), kopi (Jamil, 2019) dan nenas (Suprehatin, 2006), Untuk kelapa, hasil penelitian empiris tersebut menunjukkan produk kelapa dan manufaktur kelapa Indonesia memiliki daya saing. Produk kelapa Indonesia secara keseluruhan memiliki keunggulan kompetitif lebih tinggi dari India, Tanzania, Brazil, Thailand, Meksiko dan Malaysia namun lebih rendah daripada Filipina dan Sri Lanka (Widyantari, 2013). Produk minyak kelapa olahan Indonesia memiliki keunggulan kompetitif yang tinggi (Subangka, 2017; Subekti, Hadi \& Tety, 2018; Aulia et al., 2020) namun lebih rendah daripada Filipina (Subangka, 2017). Seperti Filipina, Indonesia juga memiliki daya saing kuat dan cenderung berposisi sebagai negara pengekspor produk tepung kelapa serta agribisnis kelapa Indonesia termasuk kategori sangat matang (Subekti, Hadi \& Tety, 2018).

Berbeda dengan penelitian-penelitian tentang daya saing kelapa tersebut, penelitian ini fokus mengkaji daya saing untuk empat produk primer kelapa Indonesia yaitu kelapa parut atau kering, kelapa di dalam kulit, kelapa segar serta olahannya dan kopra. Berdasarkan hal tersebut, penelitian ini bertujuan menganalisis posisi daya saing produk primer kelapa Indonesia terhadap masing-masing negara eksportir utama di pasar global dan menganalisis hubungan daya saing produk primer kelapa Indonesia dengan negara eksportir utama dunia di pasar global.

\section{METODE PENELITIAN}

Penelitian menggunakan data panel sekunder dengan periode tahun 2012-2017 karena berkaitan dengan ketersediaan data. Pengumpulan dan pengolahan data dilakukan pada bulan Januari-Juli 2019. Negara-negara yang menjadi objek penelitian adalah lima negara eksportir utama dari masing-masing produk primer kelapa. Produk kelapa dan turunan kelapa yang dikaji dalam penelitian ini adalah produk yang berwujud primer. Berdasar pada kode HS 1996 enam digit, produk-produk primer kelapa tersebut yaitu HS 080111 (kelapa parut atau kering), HS 080112 (kelapa di dalam kulit), HS 080119 (kelapa segar dan olahannya) dan HS 120300 (kopra). Secara rinci, data yang digunakan dalam penelitian ini yaitu nilai total ekspor seluruh komoditas dunia, nilai total ekspor masing-masing produk primer dunia, nilai total ekspor seluruh komoditas negara-negara eksportir utama produk primer kelapa dunia, nilai total ekspor masing-masing produk primer kelapa negaranegara eksportir utama produk primer kelapa dunia serta nilai total impor masing-masing produk primer kelapa negara-negara eksportir utama produk primer kelapa dunia. Seluruh data dalam penelitian ini tersebut bersumber dari Trademap (Trademap, 2019).

Analisis yang digunakan dalam penelitian ini adalah analisis data kuantitatif. Metode yang digunakan adalah analisis Revealed Symmetric Comparative Advantages (RSCA) (lihat Sanidas and Shin, 2010; Laursen, 2015) yang dikembangkan dari Balassa's Revealed Comparative Advantage Index (Balassa, 1977), Indeks Spesialisasi Perdagangan (ISP) (lihat Kemendag, 2019) dan korelasi Rank Spearman (lihat Gujarati, 2012). RSCA digunakan untuk mengetahui keunggulan komparatif suatu komoditas. RSCA adalah metode menormalisasi hasil dari perhitungan RCA. Hasil yang didapatkan dari perhitungan RSCA adalah -1 sampai dengan 1. Suatu komoditas memiliki keunggulan komparatif apabila nilai RSCA yang didapat lebih dari 0 (Sanidas \& Shin, 2010). ISP digunakan untuk mengetahui posisi atau tahapan perkembangan produk kelapa dan turunan kelapa suatu negara apakah cenderung menjadi negara eksportir atau importir, yaitu tahap pengenalan $(-1.0<$ nilai indeks ISP<-0.5), substitusi impor $(-0.5<$ nilai indeks ISP $<-0.0)$, pertumbuhan $(0.01<$ nilai indeks ISP $<0.8)$, kematangan $(0.81<$ nilai indeks ISP $<1.00)$ dan kembali mengimpor $(0.0<$ nilai indeks ISP menurun <1) (Kemendag, 2019). Korelasi Rank Spearman untuk mengetahui hubungan dua variabel (Gujarati, 2012), dalam hal ini daya saing antar negara eksportir utama produk primer kelapa, yaitu variabel nilai RSCA negara A dan variabel nilai RSCA negara B. Kedua variabel dinyatakan saling berhubungan signifikan apabila nilai p-value lebih kecil dari derajat alpha. Taraf nyata yang digunakan dalam penelitian ini adalah taraf nyata $5 \%$. Nilai rs paling kecil adalah -1 dan paling besar $+1(-1 \leq \mathrm{rs} \leq 1)$ (Gujarati, 2012). Nilai positif berarti bahwa hubungan variabel X dan Y searah sedangkan nilai negatif berarti bahwa 
hubungan variabel $\mathrm{X}$ dan $\mathrm{Y}$ berlawanan arah. Analisis pangsa pasar juga dilakukan untuk mengetahui kondisi persaingan di pasar global dari produk primer kelapa yang dikaji. Penelitian ini juga mendeskripsikan pangsa pasar negara eksportir utama keempat produk primer kelapa yang dikaji. Pangsa pasar yang dimaksud adalah penjualan relatif untuk suatu pihak terhadap pesaing di pasar yang sama (Pearce, Robinson \& Subramanian, 2000). Pangsa pasar dihitung dengan cara membagi total penjualan produk suatu negara dengan total penjualan produk suatu industri.

\section{HASIL DAN PEMBAHASAN}

Posisi Daya Saing Produk Primer Kelapa Indonesia. Analisis daya saing produk primer kelapa Indonesia terhadap masing-masing negara eksportir utama di pasar global dilakukan untuk empat produk primer kelapa yaitu kelapa parut atau kering, kelapa di dalam kulit, kelapa segar serta olahannya dan kopra. Pertama, produk kelapa parut atau kering (HS 080111). Negara eksportir utama kelapa parut atau kering secara berurutan mulai dari rata-rata pangsa pasar terbesar tahun 2012-2017 adalah Filipina (32.46\%), Indonesia (18.57\%), Sri Lanka (13.20\%), Vietnam (6.22\%) dan Belanda (5.32\%) (diolah dari Trademap, 2019). Belanda bukan merupakan negara produsen utama produk kelapa dunia namun menjadi salah satu negara eksportir utama produk kelapa parut atau kering karena sebagian besar ekspor produk kelapa dan turunannya ke pasar Uni Eropa dilakukan melalui perantara perdagangan Belanda (CBI 2018). Negara dengan nilai rata-rata RSCA tertinggi produk kelapa parut atau kering di pasar global pada tahun 2012-2017 adalah Sri Lanka sebesar 0.991 (Tabel 1). Selanjutnya, Filipina menempati posisi kedua dengan nilai rata-rata RSCA sebesar 0.979 diikuti oleh Indonesia (0.901), Vietnam (0.716) dan Belanda (0.220) (Tabel 1). Berdasarkan estimasi nilai ISP, Filipina (0.999), Indonesia (0.991), Sri Lanka (0.998) dan Vietnam (0.996) berada pada tahap kematangan (Tabel 1). Sementara itu, Belanda (-0.043) berada pada tahap substitusi impor (Tabel 1). Hal ini berarti bahwa Belanda lebih banyak melakukan impor daripada ekspor. Belanda merupakan dua negara pengekspor ulang kelapa parut atau kering terbesar di Eropa. Pangsa ekspor kelapa parut atau kering Belanda dari Uni Eropa sebesar 38.0\% kemudian diikuti oleh Belgia (36.0\%), Jerman (13.0\%), Inggris (3.0\%), Polandia (2.0\%), dan negara Uni Eropa lainnya (8.0\%) (CBI, 2015).

Tabel 1. Hasil estimasi RSCA dan ISP negara eksportir utama kelapa parut atau kering tahun 2012-2017

\begin{tabular}{lrrrrr}
\hline & Filipina & Indonesia & Sri Lanka & Vietnam & Belanda \\
\hline Rata-rata RSCA & 0.979 & 0.901 & 0.991 & 0.716 & 0.220 \\
Rata-rata ISP & 0.999 & 0.991 & 0.998 & 0.996 & -0.043 \\
Interpretasi ISP & Kematangan & Kematangan & Kematangan & Kematangan & Substitusi Impor \\
\hline
\end{tabular}

Sumber: Trademap (2019), diolah

Kedua, produk kelapa di dalam kulit (HS 080112). Berdasarkan dari Trademap (2019), negara eksportir utama kelapa di dalam kulit adalah Indonesia (39.09\%), Sri Lanka (7.09\%), Vietnam (5.33\%), Thailand (3.17\%) dan Pantai Gading (0.54\%) (diolah dari Trademap, 2019). Indonesia memiliki nilai rata-rata RSCA produk kelapa di dalam kulit tertinggi yaitu sebesar 0.943 dibandingkan dengan Sri Lanka (0.650), Vietnam (0.504), Thailand (-0.007) dan Pantai Gading (-0.552) (Tabel 2). RSCA Indonesia selalu bernilai positif dan menunjukkan tren meningkat dengan rata-rata pertumbuhan tahunan sebesar $0.02 \%$. Perhitungan ISP dari Sri Lanka dan Pantai Gading tidak dapat dilakukan karena negara tersebut pernah tidak melakukan ekspor pada rentang tahun 2012-2017. Indonesia (0.999) dan Vietnam (0.911) berada pada tahap kematangan karena ratarata nilai ISP berkisar antara 0.81 hingga 1.00 (Tabel 2). Sementara itu, Thailand berada di tahap perluasan ekspor dengan nilai ISP sebesar 0.729 (Tabel 2). 
Tabel 2. Hasil estimasi RSCA dan ISP negara eksportir utama kelapa di dalam kulit tahun 2012-2017

\begin{tabular}{lrrrrr}
\hline & Indonesia & Thailand & Vietnam & Sri Lanka & Pantai Gading \\
\hline Rata-rata RSCA & 0.943 & -0.007 & 0.504 & 0.650 & -0.552 \\
Rata-rata ISP & 0.999 & 0.729 & 0.911 & tad & tad \\
Interpretasi ISP & Kematangan & Perluasan ekspor & Kematangan & - & - \\
\hline
\end{tabular}

Keterangan: tad (tidak ada data)

Sumber: Trademap (2019), diolah

Ketiga, kelapa segar dan olahannya (HS 080119). Negara eksportir utama kelapa segar dan olahannya adalah India (22.38\%), Thailand (16.56\%), Vietnam (16.21\%), Indonesia (12.84\%) dan Belanda (4.25\%) (diolaah dari Trademap, 2019). Berdasarkan perhitungan RSCA, keseluruhan negara eksportir utama memiliki keunggulan komparatif produk kelapa segar dan olahannya di pasar dunia. Keunggulan komparatif tertinggi ada pada Vietnam dengan rata-rata nilai RSCA sebesar 0.891 pada tahun 2012-2017 (Tabel 3). Pada rentang tahun yang sama, rata-rata nilai RSCA Thailand sebesar 0.867, India 0.863, Indonesia 0.848 dan Belanda 0.107 (Tabel 3). Dari kelima negara eksportir utama kelapa segar dan olahannya ke pasar global, hanya ada tiga negara yang telah mencapai tahap kematangan yaitu India, Vietnam dan Indonesia (Tabel 3). India tiga kali mencapai nilai maksimum hasil estimasi ISP yaitu tahun 2014, 2015 dan 2016. Hal ini dikarenakan India melakukan impor yang sangat kecil dibandingkan ekspornya pada ketiga tahun tersebut. Sementara itu, Thailand berada pada tahap perluasan ekspor dan Belanda berada pada tahap substitusi impor (Tabel 3).

Tabel 3. Hasil estimasi RSCA dan ISP negara eksportir utama kelapa segar dan olahannya tahun 2012-2017

\begin{tabular}{lrrrrr}
\hline & India & Thailand & Vietnam & Indonesia & Belanda \\
\hline Rata-rata RSCA & 0.863 & 0.867 & 0.891 & 0.848 & 0.107 \\
Rata-rata ISP & 0.999 & 0.270 & 0.983 & 0.950 & -0.029 \\
Interpretasi ISP & Kematangan & Perluasan ekspor & Kematangan & Kematangan & Substitusi impor \\
\hline
\end{tabular}

Sumber: Trademap (2019), diolah

Keempat, produk kopra (HS 120300). Negara pengekspor utama produk kopra adalah Papua Nugini (25.82\%), Indonesia (21.09\%), India (10.83\%), Kepulauan Solomon (9.96\%) dan Mesir (9.87\%) (diolah dari Trademap, 2019). Berdasarkan perhitungan RSCA, diketahui bahwa Kepulauan Solomon memiliki keunggulan komparatif paling tinggi dengan rata-rata nilai RSCA sebesar 0.999 tahun 2012-2017 (Tabel 4). Hal ini dikarenakan Kepulauan Solomon menjadikan kopra sebagai salah satu komoditas unggulan negaranya. Keunggulan komparatif tertinggi produk kopra setelah Kepulauan Solomon secara berurutan yaitu Papua Nugini (0.996), Mesir (0.950), Indonesia (0.897) dan India (0.617) pada rentang tahun yang sama (Tabel 4). Berdasarkan hasil estimasi ISP diketahui bahwa keseluruhan negara utama pengekspor kopra berada pada tahap pematangan (Tabel 4). Papua Nugini mencapai nilai ISP tertinggi yaitu 1. Hal ini dikarenakan Papua Nugini dalam rentang waktu 2012-2017 tidak pernah melakukan impor produk kopra. Hal yang hampir sama terjadi di negara Kepulauan Solomon. Negara ini hanya melakukan impor kopra pada tahun 2015. Impor kopra Kepulauan Solomon sebesar 27 ribu USD pada tahun tersebut membuat nilai ISP negara tersebut mengalami penurunan menjadi 0.999 (Tabel 4). Indonesia sendiri dari tahun 2012 hingga tahun 2017 melakukan impor kopra dalam jumlah kecil. Pada rentang tahun tersebut, Indonesia selalu melakukan impor kopra dari negara Timor Leste (Trademap, 2019). 
Al Naufal. H dan Suprehatin : Daya Saing Produk Kelapa Indonesia dan Eksportir Kelapa Utama ...........

Tabel 4. Hasil estimasi RSCA dan ISP negara eksportir utama kopra tahun 2012-2017

\begin{tabular}{lrrrrr}
\hline & Papua Nugini & Indonesia & India & Kepulauan Solomon & Mesir \\
\hline Rata-rata RSCA & 0.996 & 0.897 & 0.617 & 0.999 & 0.950 \\
Rata-rata ISP & 1.000 & 0.990 & 0.875 & 0.999 & 0.994 \\
Interpretasi ISP & Kematangan & Kematangan & Kematangan & Kematangan & Kematangan \\
\hline
\end{tabular}

Sumber: Trademap (2019), diolah

Berdasarkan analisis yang telah dilakukan, dapat dilihat bahwa negara produsen utama kelapa dunia tidak selalu menjadi negara eksportir utama maupun negara dengan daya saing tertinggi produk primer kelapa. Hal tersebut dibuktikan dengan posisi Belanda, Pantai Gading, Kepulauan Solomon dan Mesir yang menjadi salah satu negara eksportir utama produk primer kelapa. Keempat negara tersebut juga memiliki daya saing pada produk primer kelapa yang mereka ekspor kecuali Pantai Gading. Sementara itu, untuk Indonesia sendiri, seluruh produk primer kelapa Indonesia di pasar global memiliki daya saing yang berada pada posisi lima besar. Produk kelapa parut atau kering Indonesia memiliki daya saing pada peringkat ketiga setelah Filipina dan Sri Lanka (Tabel 1). Kelapa di dalam kulit Indonesia memiliki daya saing pada peringkat pertama (Tabel 2). Daya saing kelapa segar dan olahan kelapa segar Indonesia berada pada peringkat keempat setelah Vietnam, Thailand dan India (Tabel 3). Kopra Indonesia berada pada peringkat keempat dengan daya saing tertinggi setelah Kepulauan Solomon, Papua Nugini dan Mesir (Tabel 4). Keseluruhan produk primer kelapa Indonesia tersebut telah mencapai tahap kematangan karena nilai rata-rata ISP tahun 2012-2017 berkisar antara 0.81 hingga 1 (Tabel 1-4).

Hubungan Daya Saing Produk Primer Kelapa Indonesia. Tujuan kedua penelitian ini yaitu menganalisis hubungan daya saing produk primer kelapa Indonesia dengan negara eksportir utama dunia di pasar global. Hasil penelitian menunjukkan bahwa berdasarkan analisis korelasi Rank Spearman, Indonesia hanya memiliki hubungan daya saing di pasar global dengan tiga negara eksportir utama untuk produk primer kelapa yang berbeda yaitu Filipina untuk produk kelapa parut atau kering, Thailand untuk produk kelapa di dalam kulit dan Papua Nugini untuk kopra (Tabel 5). Untuk produk kelapa dalam kulit, Indonesia memiliki hubungan daya saing yang tinggi $(\mathrm{rs}=0.886$ ) dengan Thailand dikarenakan Thailand melakukan impor produk tersebut dari Indonesia. Pada tahun 2017, Indonesia mengekspor produk kelapa di dalam kulit ke Thailand sebesar 46618 ribu USD meningkat dari tahun yang hanya sebesar 7132 ribu USD (Trademap, 2019).

Tabel 5. Korelasi daya saing Indonesia dengan negara-negara eksportir utama lainnya

\begin{tabular}{lcccc}
\hline \multicolumn{1}{c}{ Produk Primer Kelapa } & \multicolumn{4}{c}{ Negara Eksportir Utama } \\
\hline Kelapa parut atau kering & Filipina & Vietnam & Sri Lanka & Belanda \\
& $\left(-0.754^{*}\right)$ & $(-0.257)$ & $(-0.058)$ & $(-0.543)$ \\
Kelapa di dalam kulit & Thailand & Vietnam & Sri Lanka & Pantai Gading \\
& $\left(0.886^{* *}\right)$ & $(-0.600)$ & $(-0.143)$ & $(0.676)$ \\
Kelapa segar serta olahannya & Thailand & Vietnam & India & Belanda \\
& $(-0.486)$ & $(-0.086)$ & $(-0.600)$ & $(0.429)$ \\
Kopra & Papua Nugini & Mesir & India & Kepulauan \\
& $\left(-0.845^{* *}\right)$ & $(0.543)$ & $(-0.257)$ & Solomon $(0.131)$ \\
\hline
\end{tabular}

Keterangan: angka di dalam kurung adalah nilai koefisien korelasi Rank Spearman; **korelasi signifikan pada taraf nyata $5 \%$; *korelasi signifikan pada taraf nyata $10 \%$

Pada produk kopra, Indonesia memiliki hubungan daya saing yang negatif ( $\mathrm{rs}=-0.845$ ) dengan Papua Nugini berarti bahwa pada tahun-tahun tertentu ekspor produk kopra Indonesia tinggi namun ekspor Papua Nugini rendah. Sebaliknya, ketika ekspor produk Indonesia rendah maka ekspor Papua Nugini rendah. Kondisi 
ini terjadi karena kedua negara mengekspor kopra ke pasar yang sama yaitu Filipina. Pada tahun 2017, ekspor Papua Nugini ke Filipina sebesar 52504 ribu USD sedangkan ekspor Indonesia ke Filipina sebesar 4455 ribu USD. Pangsa pasar Papua Nugini di Filipina pada tahun tersebut sebesar 52.10\% sedangkan Indonesia hanya sebesar $4.42 \%$ (Trademap, 2019).

\section{KESIMPULAN}

Seluruh produk kelapa Indonesia di pasar global memiliki daya saing yang berada pada posisi lima besar. Produk kelapa parut atau kering Indonesia memiliki daya saing pada peringkat ketiga setelah Filipina dan Sri Lanka. Kelapa di dalam kulit Indonesia memiliki daya saing pada peringkat pertama. Daya saing kelapa segar dan olahan kelapa segar Indonesia berada pada peringkat keempat setelah Vietnam, Thailand dan India. Kopra Indonesia berada pada peringkat keempat dengan daya saing tertinggi setelah Kepulauan Solomon, Papua Nugini dan Mesir. Keseluruhan produk kelapa tersebut telah mencapai tahap kematangan. Sementara itu dilihat dari korelasi daya saingnya, produk kelapa Indonesia berkorelasi kuat dengan tiga negara yaitu Filipina untuk produk kelapa parut atau kering, Thailand untuk produk kelapa di dalam kulit dan Papua Nugini untuk kopra. Indonesia diharapkan perlu menjalin kerja sama dengan negara-negara yang memiliki korelasi kuat dari masing-masing produk primer kelapa tersebut. Dengan dilakukannya kerja sama tersebut diharapakan dapat memengaruhi harga di pasar global. Selain itu, Indonesia juga perlu meningkatkan produktivitas produk kelapa parut atau kering, kelapa segar dan olahan kelapa segar serta kopra dengan tujuan dapat menempati posisi daya saing yang lebih tinggi di pasar global.

\section{DAFTAR PUSTAKA}

Asrol, A. dan Heriyanto, H. 2017. 'Daya Saing Ekspor Pala Indonesia di Pasar Internasional', Dinamika pertanian, 33(2), pp. 179-188.

Aulia, A. N. et al. 2020. 'Competitiveness and Export Similarity of Indonesia's Coconut Oil', Jurnal Agribest, 4(2), pp. 123-132.

Balassa, B. 1977. "Revealed'comparative advantage revisited: An analysis of relative export shares of the industrial countries, 1953-1971', The Manchester School, 45(4), pp. 327-344.

Bourdeix, R. and Prades, A. 2018. 'A global strategy for the conservation and use of coconut genetic resources, 2018-2028’. Biodiversity International.

Caporale, G. M., Spagnolo, F., and Spagnolo, N. 2018. 'Exchange rates and macro news in emerging markets, Research in International Business and Finance, 46, pp. 516-527.

CBI ., 2015 Exporting Desiccated Coconut to Europe. Available at: https://www.cbi.eu/marketinformation/processed-fruit-vegetables-edible-nuts/desiccated-coconuts/europe (Accessed: 4 July 2019).

Dharmawan, A. et al. 2020. 'Techno-Economic Evaluations on the Liquid Smoke Production from Coconut Shells (Case Study at CV Prima Rosandries, Jember)', Jurnal Penelitian Pertanian Terapan, 20(2), pp. $126-134$.

Dhiman, R., Kumar, V., and Rana, S. 2020. 'Why export competitiveness differs within Indian textile industry? Determinants and empirical evidence', Review of International Business and Strategy, 20(3), pp. 375-397.

Ditjenbun., 2016. Statistik Perkebunan Indonesia 2015-2017: Kelapa. Jakarta: Ditjenbun Kementan.

Gujarati, D. 2012. Econometrics by example. Macmillan.

Jamil, A. S. 2019. 'Daya Saing Perdagangan Kopi Indonesia di Pasar Global', Agriekonomika, 8(1), pp. 2635. 
Al Naufal. H dan Suprehatin : Daya Saing Produk Kelapa Indonesia dan Eksportir Kelapa Utama.....

Kemendag., 2019. Indeks Spesialisasi Perdagangan (ISP). Available at: https://www.kemendag. go.id/addon/isp/ (Accessed: 7 July 2019).

Laursen, K. 2015. 'Revealed comparative advantage and the alternatives as measures of international specialization', Eurasian business review. Springer, 5(1), pp. 99-115.

Paul, J. and Dhiman, R. 2021. 'Three decades of export competitiveness literature: systematic review, synthesis, and future research agenda', International Marketing Review, 26(4), pp. 472-492.

Pearce, J. A., Robinson, R. B. and Subramanian, R. 2000. Strategic management: Formulation, implementation, and control. Irwin/McGraw-Hill Columbus, $\mathrm{OH}$.

Porter, M. E. 2011. Competitive advantage of nations: creating and sustaining superior performance. New York (USA): Free Press.

Pusdatin., 2017. Petunjuk Teknis Cakupan Kode HS Penyusun Data Ekspor Impor Komoditas Pertanian Berdasarkan Klasifikasi BKTI 2017. Jakarta.

Rifin, A. 2019. 'The Progressive Export Tax and Indonesia's Palm Oil Product Export Competitiveness', Buletin Ilmiah Litbang Perdagangan, 13(2), pp. 211-232.

Sanidas, E. and Shin, Y. 2010. 'Comparison of revealed comparative advantage indices with application to trade tendencies of East Asian countries, in 9th Korea and the World Economy Conference, Incheon.

Satryana, M. H. dan Karmini, N. L., 2016. 'Analisis Daya Saing Ekspor Teh Indonesia ke Pasar ASEAN Periode 2004-2013', E-Jurnal Ekonomi Pembangunan Universitas Udayana. Udayana University, 5(5), p. 165172.

Sharples, J. A., and Milham, N., 1990. Long-run competitiveness of Australian agriculture. 147996. New York.

Subangka, W., 2017. Faktor-faktor yang Memengaruhi Daya Saing Minyak Kelapa Olahan Indonesia ke Negara Utama Tujuan Ekspor. IPB University.

Subekti, Y., Hadi, S. dan Tety, E., 2018. 'Daya Saing Ekspor Produk Kelapa Indonesia di Pasar Internasional', PEKBIS (Jurnal Pendidikan Ekonomi Dan Bisnis), 10(1), pp. 39-52.

Suprehatin, S., 2006. 'Analisis Daya Saing Ekspor Nenas Segar Indonesia', Jurnal Ilmu Pertanian Indonesia, 11(2), pp. 42-48.

Trademap., 2019. List of Exported Products for the Selected Product. Available at: https://www.trademap.org/Product_SelProduct_TS.aspx (Accessed: 13 April 2019).

Tresliyana, A., Fariyanti, A. dan Rifin, A., 2015. 'Daya Saing Kakao Indonesia di Pasar Internasional', Jurnal manajemen \& agribisnis, 12(2), p. 150.

Widyantari, I. N. 2013. 'Daya Saing Ekspor Komoditas Kelapa Indonesia terhadap Tiga Negara di Asia', AGRICOLA, 3(2), pp. 128-135. 